\title{
Do Consumers Pay Attention to the Organic Label When Shopping Organic Food in Italy?
}

\author{
Tiziana de Magistris and Azucena Gracia \\ Centro de Investigación y Tecnología Agroalimentaria de Aragón \\ Spain
}

\section{Introduction}

The main objective of organic agriculture is to produce healthy and quality food products without using synthetic chemical products in response to consumers' concerns about food safety, human health, animal welfare and the environment. The EU's promotion of organic agriculture constitutes an important alternative for society and for the more marginal agricultural regions in southern Europe.

First, organic agriculture provides consumers some products with higher nutritional value that are free of chemical agents. Second, it improves public health, and it brings significant benefits both to the economy as well as to the social cohesion of rural areas.

Organic label is a quality signal for the consumers and an important tool to help them to identify organic products. Yiridoe et al. (2005) stated that product labels can help buyers to assess product quality by transforming credence characteristics into search attributes. On 1 July 2010, the European Union introduced a new organic logo in order to increase the transparency and confidence in organic food products for consumers. The difference from the first logo, introduced in the 1990s, is its compulsory basis (EU n. 271/2010 of 24 March 2010) for those products in which at least $95 \%$ of the agricultural ingredients are organics. According to the European Union, the application of the new logo and labeling will lead to a much greater visibility of organic foods in the market and increase the trust among European citizens, who will be not only more informed but also more willing to purchase these products (Council Regulation (EC) No. 834/2007 of 28 June 2007).

Therefore, understanding the reason why consumers choose to buy organic products and investigating whether they pay attention to organic labeling when shopping are necessary in order to induce new individuals to buy organic food products and to increase the level of consumption among existing consumers.

The aim of our chapter is to analyze whether Italian consumers pay attention to organic labeling when shopping, and whether they are also affected by other psychological variables to make purchase decisions. We carried out a study on the intention to purchase organic food products, proposing a model of organic consumption which has been developed on the Theory of Planned Behavior by Ajzen (1991), which extends it with a new variable related to consumers' attention to organic label which has not been yet analyzed in Italy.

To achieve this goal, a survey was conducted with 380 food shoppers during NovemberDecember 2008 in Italy, and three-equation multivariate probit model is fitted, where 
consumers' attention to organic label, the intention to purchase, and organic consumption are the dependent variables. Findings show that paying attention to organic labeling influences the intention to purchase organic food products. Moreover, attitudes and lifestyles are the best predictors of organic purchase. However, environmental attitudes and subjective norms do not affect the intention to purchase them, while ethical dimension is considered one of main factors driving organic food purchases.

The rest of the chapter is structured as follows. Section 2 develops the theoretical framework where the relationship among endogenous and exogenous variables of our model are justified by literature review. Section 3 describes an overview of the European legislation on organic food labeling; Section 4 focuses on the data gathered and methodology. Section 5 shows the main results; and, finally, Section 6 concludes with a discussion of the marketing and policy implications.

\section{Literature review}

In general, research on the organic purchase intention is well documented in the academic literature (Saba and Messina, 2003; Tarkiainen and Sundqvist, 2005; Chen, 2007; Chen, 2008; Thogersen, 2007a; Dean et al., 2008; de Magistris and Gracia, 2009; Aertsen et al., 2009). Some studies analyzed the intention to purchase organic food products using the Theory of Planned Behavior (Ajzen, 1991) where the intention is considered the best predictor of behavior. In accordance with the TPB, the attitudes toward action sequence, as well as the relations among factors on the intention have been part of the general approach to attitudes in social psychology. A major theoretical position on attitudes and action has been formulated by Ajzen (1991) as the Theory of Planned Behavior (TPB), where the behavioural intention is basically determined by three factors: attitudes, subjective norms and perceived behavioural control. Attitudes are composed of behavioural beliefs and outcome evaluations of the consequences of beliefs. Subjective norms refer to perceived social pressure to perform or not perform the behaviour as perceived by the person. Finally, perceived behavioural control is the individual's beliefs about the amount of control that an individual has to successfully complete his/her behaviour (Ajzen, 1991).

Findings revealed that consumers' attitudes towards organic attributes (taste, health, food safety, environmentally friendly, animal welfare) and salient beliefs (attitudes towards its purchase, personal moral norms, ethical motivations and emotions ) are the most important factors that explain consumers' decision-making process for organic food (Magnusson et al, 2001; Thøgersen, 2002; Saba and Messina, 2003; Millok et al., 2004; Verhoef, 2005; Tarkiainen and Sundqvist, 2005; Padel and Foster, 2005; Chryssohoidis and Krystallis, 2005; Honkanen et al., 2006; Thøgersen and Olander, 2006; Chen, 2007; Chen, 2008; Dean et al., 2008; Arvola et al., 2008; Aertsen et al., 2009; Gracia and de Magistris, 2008; de Magistris and Gracia, 2009; Guido et al., 2010). The results showed significant differences across the products and countries where the research was carried out.

\subsection{Theoretical model}

\subsubsection{Attitudes}

Attitudes towards the behavior refer to the degree to which an individual has a favorable or unfavorable evaluation of the behavior (Ajzen, 1991). According to Ajzen(1991) the more favorable the attitudes are towards a behavior, the stronger is the persons' intention to perform the behavior under consideration. Some studies about organic consumers reported 
a significant positive relation between consumers' intention to purchase organic food and their attitudes toward organic food purchase (Saba and Messina, 2003; Millock et al., 2004; Chryssohoidis and Krystallis, 2005; Padel and Foster, 2005; Tarkiainen and Sundqvist, 2005; Honkanen et al., 2006; Thøgersen, 2007a; Thøgersen, 2007b ; de Magistris and Gracia ,2008)

Saba and Messina (2003) carried out their study in Italy, analyzing organic fruit and vegetable products. Findings showed that Italian consumers showed positive attitudes towards these products, perceived them as healthy, environmentally friendly, tastier and nutritious than conventional products. Millock et al. (2004) claimed that environmental and animal welfare attitudes influence organic food choice to a lesser extent than attitudes towards taste, freshness and health aspects of organic food. Chryssohoidis and Krystallis (2005) indicated that the most important motives behind the purchase of organic products in Greece are healthiness and better taste of the organic food. However, environmental motives influence organic food choice to a lesser extent. Padel and Foster (2005) concluded that consumers buy organic food products because they perceived them to be better for their health. Moreover, they found that the attitude towards environmental protection was also a factor that explains organic food buying decisions.

Tarkiainen and Sundqvist (2005) analyzed the factors that affected the purchase of organic food in Finland. The results suggested that consumers 'intentions to buy organic food are predicted by their attitudes and environmental concerns. Honkanen et al. (2006) studied the motives driving organic food choice in Norwegian consumers. The findings indicated that ecological motives and attitudes towards organic food have a significant influence on the intention to purchase organic food. Similar results were found by Thøgersen (2007b) who stated that health, taste and environmental consequences were the most important factors related to organic consumers' attitudes toward buying organic tomato juice. Along the same line, de Magistris and Gracia (2008) investigated the organic purchase behavior of Italian consumers. They found that consumers' attitudes towards organic food, in particular towards the health attributes and towards the environment are the most important factors explaining organic food purchase

\subsubsection{Subjective norms}

Ajzen (1991) identified also the role of subjective norms, which refer to the perceived social pressure to perform or not to perform the behavior. In other words, subjective norm is an individual's conviction that acting in a certain way is right or wrong regardless of personal or social consequences. Few studies, however, have examined subjective norms in relation to organic food purchases.

Sparks and Shepherd (1992) included subjective norms in their study of green consumers, but their explanatory power was relatively weak, even though significant. Tarkiainen and Sundqvist (2005)) investigated the correlation between subjective norms and attitudes towards organic food. The authors suggested that the link could be explained by the information that individuals have towards social environment. However, the authors did not find direct significant relation between subjective norms and the intention to buy organic foods. On the other hand, Thøgersen (2007b), and Dean et al. (2008) found a significant positive relation between consumers' intention to purchase organic food and their subjective norms. Finally, Smith and Paladino (2010) in their study of organic consumers in Australia stated that subjective norms are significant factors influencing the decision-making of consumers. 


\subsubsection{Perceived behavioural control}

Perceived control is the "perception of the ease or difficulty of performing the behavior of interest anticipating some obstacles" (Ajzen, 1991). In the context of organic consumer behavior, price and availability potentially limit organic purchases. The past research of organic consumption has shown that the most important reasons for not buying organic food are lack of availability and organic food's relatively higher price compared to conventional food products. (Magnusson et al., 2001; Fotopoulos and Krystallis, 2002; Zanoli and Naspetti, 2002; Padel and Foster, 2005; Chryssohoidis and Krystallis, 2005). However, Canavari et al. (2002) found that 30 per cent of consumers are willing to pay a price premium directly to farmers.

\subsubsection{Ethical dimension}

In literature on organic consumer behavior, major extension of the TPB is related to the ethical dimension, defined by Shaw and Clarke (1999) as "the degree to which consumers prioritize their own ethical concerns when making products choices." Some studies used different variables in order to take into account ethical dimension in organic consumer behavior. To illustrate, Michaelidou and Hassan (2008) used self-identify concept defined as the enduring characteristics that people ascribe to themselves. The authors found that selfidentity affected the intention to buy organic food products. Honkanen et al. (2006) mentioned ethical values based on environmental and animal protection in order to explain organic behavior, while Arvola et al. (2008) applied moral norms, defined as an individual's conviction that acting in a certain way is right or wrong regardless of their personal or social consequences, to demonstrate their strong influence on the consumption of organic food in Italy and in the United Kingdom.

\subsubsection{Socio-demographic variables and lifestyles}

Socio-demographic characteristics were found to be significant in explaining the decision to buy organic foods mainly in empirical studies conducted in Europe. Findings revealed that only sex, income, age, education and household size were significant (Canavari et al., 2002; Millock et al. 2003; Lockie et al. 2004; and Tsakiridou et al. 2006; Gracia and de Magistris, 2008). To illustrate, older, more educated consumers with high income and those living in larger households are more likely to buy organic food products.

The concept of "food-related lifestyle" was developed in the mid-1990s as a segmentation tool, which is tailored to the consumer's role as a food shopper (Grunert and Brunsø, 1997). Lifestyles are important exogenous factors in the decision-making process influencing consumer behaviour (Gil et al, 2000; Brunsø, Scholderer and Grunert, 2004). Schifferstein and Oude Ophuis (1998) stated that health behaviour, such as additional exercise and habits related to food intake, affects positively the organic food choice and Chryssohoidis and Krystallis (2005) stated that most of Greek organic buyers claimed to follow a balanced and healthy diet. de Magistris and Gracia (2009) demonstrated that lifestyles represent one of main factor explaining organic food decision-making. In particular, organic food products are preferred by those consumers interested in maintaining a particular lifestyle associated with healthy and eating habits

\subsubsection{The extension of planned behaviour model: paying attention on organic labelling and organic knowledge}

Academic studies of organic food labels have increased substantially in Europe during the last two decades. Most of the empirical works have used the hypothetical approach to assess 
consumer preferences for organic food labels to calculate consumers' Willingness to Pay (WTP) for the presence of them, implying their intention to purchase organic foods, taking into account the presence of organic label on packaging. Paying attention to organic labels depends also to the degree of self-knowledge that consumers have towards organic food products when shopping. Moreover, consumers might show a certain level of knowledge about the information that organic label provides to them such as that organic food products, free OGMs, they support the animal welfare and they content $95 \%$ of organic ingredient at least. Hence, organic food label perceived by consumers is an important issue in the organic food market because it represents the only instrument that consumers have to differentiate the attributes of organic food products from those of conventional ones, and build positive attitudes towards organic food (von Alvesleben, 1997). Moreover, Yiridoe et al. (2005), in their literature review, stated that knowledge of organic food products can affect consumers' organic buying decision for two reasons. The first one, the lack of knowledge of organic labeling is considered the number one reason why consumers do not buy organic food. The second reason is that consumers who do not consider that organic food products have enough detailed information cannot clearly differentiate the unique attributes of organic from conventionally grown alternatives. Usually, many organic food consumers identify organic products based on the organic logos and labels attached to the product. The authors concluded that information about organic food helps to transform the credence characteristic of such products into search attributes, thereby allowing the consumer to better evaluate the quality before deciding to buy the product. Organic knowledge can be considered as a part of formation that consumers acquire from organic food products. Hill and Lynchehaun (2002) found that knowledge represents an important factor influencing the purchase of organic products. Poelman et al. (2008) analyzed whether information on organic production and fair trade affects the preference for and perception of pineapples in British and Dutch individuals. The results indicated a slight positive impact of organic product information on consumers' preference and perception for pineapple. Gracia and de Magistris (2008) and de Magistris and Gracia (2009) also provided evidence on the positive influence of consumers' organic knowledge on purchasing behavior. Based on these previous findings, the model of intention to purchase organic food products is presented in figure 3 .

\section{EU organic labeling legislation}

The EU legislation on organic labeling is laid down in the following four Regulations: i) Regulation (EEC) No 2092/21, ii) Commission Regulation (EC) No 331/2000, iii) Council Regulation (EC) No. 834/2007 of 28 June 2007 and, iv) Commission Regulation (EU) No $271 / 2010$.

Regulation (EEC) n. 2092/91 was adopted in 1992 when organic agriculture received the official recognition from EU members within the EU Common Agricultural Policy. The main importance of this Regulation is it created the common minimum standards for the entire European Union inducing European citizens to trust organic products coming from other European countries. Even though plant products were regulated, additional rules were laid down later. These rules regarded animal feed, prevention of illness, veterinary treatment, animal protection, and livestock breeding. Moreover, the use of genetically modified organisms was expressly prohibited while the imports of organic products from Third Countries were allowed after being recognized as equivalent by EU. 


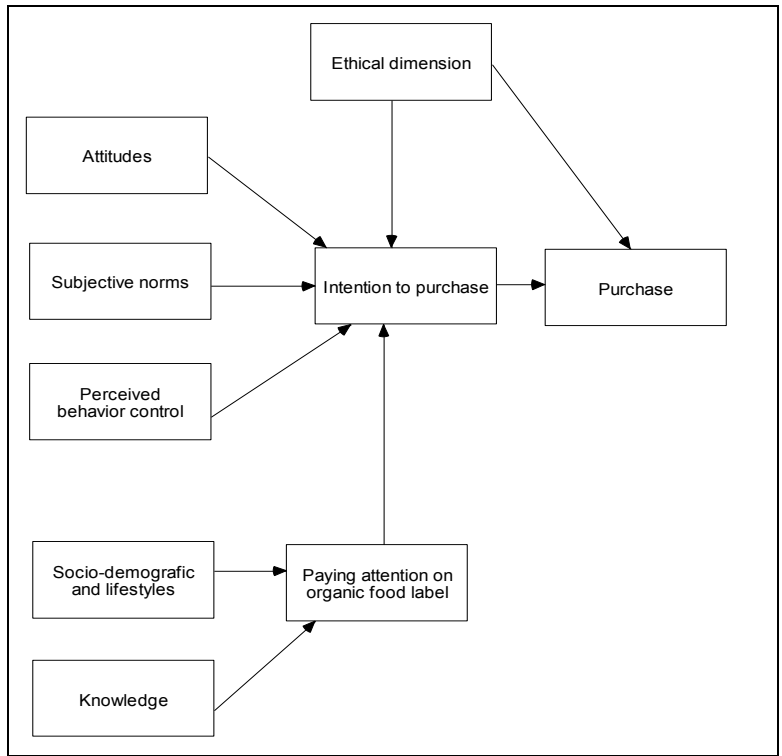

Fig. 3. Model of intention to purchase organic food products

The first European organic logo was introduced in March 2000 by Commission Regulation (EC) No 331/2000 bearing the words "Organic Farming-EC control systems" This logo had voluntary basis for those producers who satisfied the Regulation (EEC) No 2092/91.

The indicator that a product was covered by the inspection scheme had to be shown in the same language or languages as used for the labeling, as shown in figure 1.

Moreover, the Regulation authorized the combination of two indicators referring to the national languages, and the minimum size for a logo with a single indicator was $20 \mathrm{~mm}$ diameter while for a logo with a combination of two indicators the minimum size was $40 \mathrm{~mm}$ diameter.

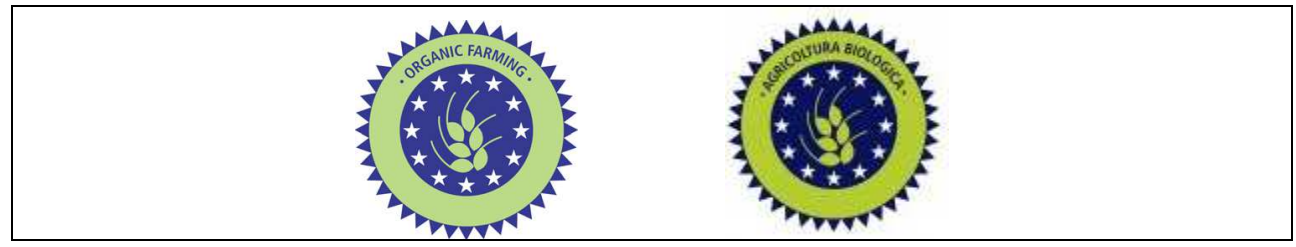

Fig. 1. Organic logo introduced in Regulation (EEC) No 2092/91.

The Regulation (EC) n. 834/2007 was laid down on June 2007, and it revises of the Regulation No 2092/91. The need to review it was prompted during a public conference titled "Is Organic farming: ready for the next decade?" in December 2006, which represented an opportunity for the 90 stakeholders in attendance to discuss a possible proposal of revision of the Organic Regulation at the European level.

The main elements of the Regulation (EC) n. 834/2007 were a new definition of organic productions; the application of organic production to aquaculture, seaweeds, wine making 
and yeast; the main labeling provisions; new rules on inspection; import and labeling, and its applicability after January 1, 2009.

According to the art. 1, organic production was defined as an overall system of farm management and food production whose function was to combine the best environmental practices, a high level of biodiversity, the preservation of natural resources, the application of animal welfare standards in order to meet consumers' demand with products of high quality. The Regulation dedicated a complete section to organic labeling rules. To illustrate, all usual common terms for "organic" in the different member states and its derivatives and diminutives were equally protected in their use. The term "organic" was not applied to agricultural products which clearly had no connection with organic production and those which contained GMOs (Genetic Modified Organisms). Nevertheless, the organic labeling had to explicate the general limit of $0.9 \%$ for the accidental presence of GMOs. Secondly, the new European logo became compulsory on packaged European products, even though national and private logos could still be used. For the first time, the organic logo was compulsory for only those food products with at least $95 \%$ of the organic ingredients whose the raw materials composed the products. The indication had to mention i) EU Agriculture where the agricultural raw material had been farmed in the EU., ii) non-EU Agriculture, where the agricultural raw material came from third world countries, and iii) EU/ non-EU Agriculture, where the origin of raw material was mixed, meaning that it had been farmed both in the UE countries and third World countries. Organic ingredients in non-organic food had to be listed as organic in the list of ingredients, while the code number of the control body had to be indicated in order to guarantee better transparency.

Since the introduction of a new logo was supported by all European States, the European Commission organized an EU-wide organic logo competition opened to art and design students from all EU countries. The competition was won by the German design student Dušan Milenković, who received 63\% of the overall votes from the European public. Hence, European Union launched a second certifying symbol in the Regulation 271/2010 where the organic logo was definitively mandatory, also called: "Euro-leaf" which symbolized the marriage of Europe (the stars derived from the European flag) and Nature (the stylized leaf and the green color), as shown in figure 2. In accordance with this last regulation, there will be a two year transition period for allowing its introduction on the packaging.

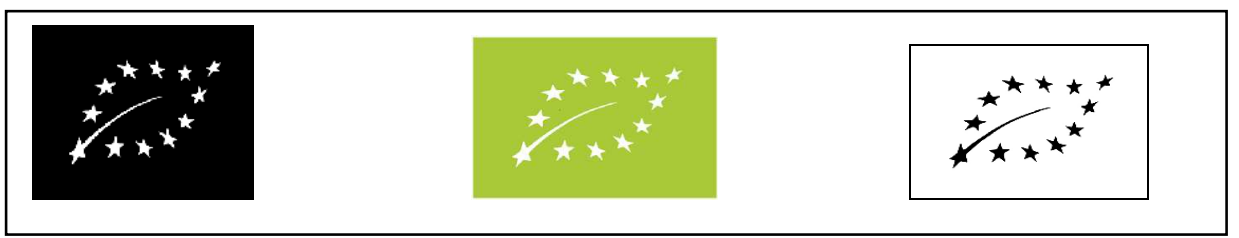

Fig. 2. Organic logo introduced in Commission Regulation 271/2010

In Italy, the certification bodies, which carry out the organic certification, are authorized by the Ministry of Agriculture. They are private entities and their main task is to ensure compliance with the implementation of regulations by the organic farms and give their own brand labels to be affixed to products sold. To illustrate, certification body has own brand label which has to be used only by those organic farmers associated to it in order to avoid that one organic farmer achieves organic certification from more than certification enterprise. In general, they do not have to entertain any relationship with organic farms and they carry out inspections every year. The inspection consists in compliance with 
regulations and collecting some sample for testing at ARPAT or at a laboratory accredited Sinal (Sistema Nazionale per l'Accreditamento di Laboratori).

In Italy, there are 17 certification bodies recognized and their activity is constantly under control of the Region where they are placed. Moreover, 14 certification bodies over 17 are located in the Centre and North of Italy, whereas only two of them carry out their activity in Southern Italy. In particular, BIKO, IMO Gmbh and Q.C. \& I. have been recognized to operate in Bolzano province.

\begin{tabular}{|c|c|}
\hline ABCERT Srl - Cod. Min. IT BIO 013 & $\begin{array}{l}\text { Terlano (BZ) } \\
\text { Web: http://www.abcert.it }\end{array}$ \\
\hline $\begin{array}{l}\text { BIKO - Kontrollservice Tirol (Cod. Min. IT - BIO } \\
\text { - } 001 \text { - BZ) }\end{array}$ & $\begin{array}{l}\text { INNSBRUCK - Austria } \\
\text { Web: http://www.biko.a }\end{array}$ \\
\hline $\begin{array}{l}\text { Bioagricert S.r.l. - Cod. Min. IT BIO } 007 \text { - (ex BAC) } \\
\text { E-mail: info@bioagricert.org }\end{array}$ & $\begin{array}{l}\text { Casalecchio di Reno BO } \\
\text { Web: http://www.bioagricert.org }\end{array}$ \\
\hline BIOS S.r.l. - Cod. Min. IT BIO 005 - (ex BSI) & $\begin{array}{l}\text { Marostica VI } \\
\text { Web: http://www.certbios.it }\end{array}$ \\
\hline BIOZOO - S.r.l. - Cod. Min. IT BIO 010 - (ex BZO) & $\begin{array}{l}\text { Sassari SS } \\
\text { Web: http://www.biozoo.org }\end{array}$ \\
\hline CCPB S.r.1. - Cod. Min. IT BIO 009 - (ex CPB) & $\begin{array}{l}\text { Bologna BO } \\
\text { Web: http:// www.ccpb.it/ }\end{array}$ \\
\hline CODEX S.r.l. - Cod. Min. IT BIO 002 - (ex CDX) & $\begin{array}{l}\text { Scordia CT } \\
\text { Web: http://www.codexsrl.it/ }\end{array}$ \\
\hline $\begin{array}{l}\text { EcoGruppo Italia S.r.l. - Cod. Min. IT BIO } 008 \text { - } \\
\text { (ex ECO) }\end{array}$ & $\begin{array}{l}\text { Catania CT Web: } \\
\text { http://www.ecogruppoitalia.it }\end{array}$ \\
\hline $\begin{array}{l}\text { ICEA - Istituto per la Certificazione Etica e } \\
\text { Ambientale - Cod. Min. IT BIO } 006 \text { - (ex ICA) }\end{array}$ & $\begin{array}{l}\text { Bologna } \\
\text { Web: http:// www.icea.info/ }\end{array}$ \\
\hline $\begin{array}{l}\text { IMC - Istituto Mediterraneo di Certificazione } \\
\text { S.r.l. - Cod. Min. IT BIO } 003 \text { - (ex IMC) }\end{array}$ & $\begin{array}{l}\text { Senigallia (AN) } \\
\text { Web: http://www.imcert.it/ }\end{array}$ \\
\hline IMO Gmbh (Cod. Min. IT - BIO - 002 - BZ) & $\begin{array}{l}8570 \text { Weinfelden } \\
\text { Web: http://www.imo.ch }\end{array}$ \\
\hline $\begin{array}{l}\text { Q.C. \& I. - Gesellschaft für kontrolle und } \\
\text { zertifizierung von Qualitätssicherungssystemen } \\
\text { GMBH (Cod. Min. IT - BIO - } 003 \text { - BZ) }\end{array}$ & $\begin{array}{l}\text { Tiergartenstr. } 32 \text { D- } 54595 \text { Prum } \\
\text { Web: http://www.qci.de }\end{array}$ \\
\hline QC S.r.l.- Cod. Min. IT BIO 014 & $\begin{array}{l}\text { Monteriggioni SI } \\
\text { Web: http://www.qcsrl.it/ }\end{array}$ \\
\hline Sidel S.p.a - Cod. Min. IT BIO 012 - (ex SDL) & $\begin{array}{l}\text { BOLOGNA BO } \\
\text { Sidel S.p.a - Cod. Min. IT BIO } 012 \text { - } \\
\text { (ex SDL) } \\
\text { Web: http:/ / www.bio.sidelitalia.it/ }\end{array}$ \\
\hline $\begin{array}{l}\text { Suolo e Salute - Direzione Tecnica e Ufficio } \\
\text { Estero - Cod. Min. IT BIO } 004\end{array}$ & $\begin{array}{l}\text { Bologna (BO) } \\
\text { Web: http://new.suoloesalute.it/ }\end{array}$ \\
\hline Suolo e Salute srl - (Cod. Min. IT - ASS & $\begin{array}{l}\text { Roseto degli Abruzzi (TE) } \\
\text { Web: http:// www.suoloesalute.it }\end{array}$ \\
\hline Suolo e Salute srl - (Cod. Min. IT 004 - ex ASS) & $\begin{array}{l}\text { Taormina (ME) } \\
\text { Web: http://www.suoloesalute.it }\end{array}$ \\
\hline
\end{tabular}

Table 1. Certification bodies recognized in Italy. 


\section{Material and methods}

\subsection{Multivariate probit model}

The three endogenous variables of the above intention to purchase model defined in figure 3 (organic food purchase, the intention to purchase and paying attention to organic food label) are discrete variables. The first equation in the model is consumers' organic food purchase $(\mathrm{OP})$, specified as follows:

$$
O P_{i}^{*}=\lambda I P_{i}^{*}+\beta X_{i}+u_{i}
$$

Where $\mathrm{IP}_{\mathrm{i}}^{*}$ is the variable related to the intention to purchase organic food products defined below, $X_{i}$ is a vector of exogenous variables related with the ethical dimension of organic purchase, and $\mathrm{u}_{\mathrm{i}}$ is the error term normally distributed $\mathrm{N}\left(0, \sigma_{u}{ }^{2}\right) . \mathrm{OP}_{\mathrm{i}}^{*}$ is unobserved; what is observed is the purchase of organic food products stated by the individual when shopping, where $\mathrm{OP}_{\mathrm{i}}^{*}=3$ means that a consumer reports that he usually purchases organic food, $I P i=2$ means that the consumer sometime buys organic food and $I P i=1$ means the consumer never has bought them. Observed and latent variables are related as follows:

$$
\begin{array}{lll}
O P_{i}=1 & \text { if } & O P_{i}^{*} \leq \tau_{1} \\
O P_{i}=2 & \text { if } & \tau_{1} \leq O P_{i}^{*} \leq \tau_{2} \\
O P_{i}=3 & \text { if } & \tau_{2} \leq O P_{i}^{*} \leq \tau_{3}
\end{array}
$$

where $\tau_{i}$ are the unknown threshold parameters to be estimated. The first threshold parameter is normalized to zero $\left(\tau_{1}=0\right)$.

The intention to purchase organic food products (IP) equation is defined as follows:

$$
I P_{i}^{*}=\lambda O R G_{-} L A B E L_{i}^{*}+\beta Y_{i}+\varepsilon_{i}
$$

where ORG_LABEL ${ }_{\mathrm{i}}^{*}$ is the variable related to consumers' paying attention to organic labels when shopping defined below, $X_{i}$ is a vector of all exogenous variables (attitudes, subjective norms, perceived behavioural control, and ethical dimension), and $\varepsilon_{\mathrm{i}}$ is the error term normally distributed $\mathrm{N}\left(0, \sigma_{u}{ }^{2}\right) . I P_{i}^{*}$ is an unobserved variable, which reflects the intention to purchase organic food products, stated by the individual when shopping and defined in 2 levels, as follows:

$$
\begin{array}{lll}
I P_{i}=1 & \text { if } & I P_{i}^{*} \geq 0 \\
I P_{i}=0 & \text { if } & I P_{i}^{*}, \leq 0
\end{array}
$$

The level of paying attention to organic labels is defined as:

$$
O R G_{-} L A B E L_{i}^{*}=\varpi Z_{i}+\xi_{i}
$$

where, $Y_{i}$ represents all the exogenous variables (socio-demographic, lifestyles and, knowledge) and $\xi_{\mathrm{i}}$ is the normally distributed error term $\mathrm{N}\left(0, \sigma_{\zeta}^{2}\right)$. ORG_LABEL ${ }_{\mathrm{i}}^{*}$ is the 
unobserved paying attention to organic label, and as before, the researchers observe an ordered level of paying attention, as follows:

$$
\begin{array}{lll}
O R G_{-} L A B E L_{i}=1 & \text { if } & O R G_{-} L A B E L_{i}^{*} \leq v_{1} \\
O R G_{-} L A B E L_{i}=2 & \text { if } & v_{1} \leq O R G_{-} L A B E L_{i}^{*} \leq v_{2} \\
O R G_{-} L A B E L_{i}=3 & \text { if } & v_{2} \leq O R G_{-} L A B E L_{i}^{*} \leq v_{3} \\
O R G_{-} L A B E L_{i}=4 & \text { if } & v_{3} \leq O R G_{-} L A B E L_{i}^{*} \leq v_{4} \\
O R G_{-} L A B E L_{j}=5 & \text { if } & v_{5} \leq O R G_{-} L A B E L_{i}^{*}
\end{array}
$$

where $v_{\mathrm{I}}$ are the unknown threshold parameters to be estimated. The first threshold parameter is normalized to zero $\left(v_{1}=0\right)$.

To estimate the three equations [1], [3] and [5], we have assumed that the error terms $\left(u_{i}, \varepsilon_{i}\right.$ and $\zeta_{\mathrm{i}}$ ) may be correlated. The, instead of estimating them independently, they are considered to be a multivariate limited-dependent-variable model, in which the three error terms $\left(\mathrm{u}_{\mathrm{i}} \varepsilon_{\mathrm{i}}\right.$ and $\left.\zeta_{\mathrm{i}}\right)$ follow a multivariate normal distribution with mean zero and variance and covariance matrix $\Omega$. The limited dependent-variable (LDV) model with correlated error terms are estimated using Hajivassiliou and McFadden's (1998) procedure implemented in Proc QLIM in the SAS 9.1 statistical software package.

\subsection{Data gathering and variables definitions}

Data were collected from a survey conducted in Italy during November-December 2008. The capital Rome was chosen for two reasons. The city can be considered a representative sample of Italy since its economic indicators, such as average expenditure on food products $(498 €)$, average household income per year $(34,000 €)$ and most demographic characteristics are very close to the economic indicators for Italy (ISTAT, 2008). Sample size was set at 380. As the population can be considered infinite, this sample size results in a sampling error of $\pm 5 \%$, assuming a confidence level of $95.5 \%(k=2)$ and $p=0.5$. A stratified random sample of consumers was made on the basis of town district and age. A number of representative grocery stores and supermarkets were selected in each town district, and food shoppers were randomly selected outside these food outlets. Target respondents were the primary food buyers in the household, and interviews were carried out face to face. Interviewers approached the randomly selected individuals asking them one screening question, whether they were the main household food shopper. The questionnaire was designed to analyze consumers' organic food knowledge, attitudes and purchase behavior.

The questionnaire format was validated using a pilot survey. The questionnaire also contained questions on socio-demographic characteristics (i.e. sex, family size and composition, age, education level, income) and lifestyles. Summary statistics for the characteristics of the full sample are presented in Table 2 . The majority of participants are female $(58 \%)$ and, on average, participants are living in households of 3 members. In addition, the average age is about 45 years. Moreover, around $15 \%$ belong to high income groups and about $48 \%$ of the subjects have a university degree.

The first question was related to their knowledge of organic food products. The level of selfreported knowledge was measured asking respondent their self-reported level of knowledge from 1 to 3 , where 3 indicate the highest level of knowledge (KNOW). Objective 
knowledge was measured by four dummy variables (GMOs, NATURAL, ANIMAL WELFARE and, 95_INGREDIENTS) which take 1 value if respondent states that organic food products are GMOs free, natural, they support the animal welfare and, they content $95 \%$ of organic ingredients at least, and 0 otherwise (see table 3 )

\begin{tabular}{|l|l|c|}
\hline \multicolumn{1}{|c|}{ Variable definition } & \multicolumn{1}{|c|}{ Name (type) } & $\begin{array}{c}\text { Value } \\
\%\end{array}$ \\
\hline $\begin{array}{l}\text { Gender } \\
\text { Male }\end{array}$ & FEMALE (dummy) & 42 \\
\hline Hemale & HSIZE (continuous) & 58 \\
\hline Age of respondent (average) & AGE & 45 \\
\hline Education of respondent & & \\
Elementary & & 8.1 \\
Secondary & UNIVERSITY (dummy) & 43.5 \\
University & & 48.4 \\
\hline Household Income: & LW_INC (dummy) & 23.1 \\
Net income lower than $1,500 € /$ month & & 63.1 \\
Net income between 1,500 and $2,500 € /$ month & & 14.8 \\
Net income higher than 2,500 $€ /$ month & & \\
\hline
\end{tabular}

Table 2. Sample characteristics

\begin{tabular}{|l|l|c|}
\hline \multicolumn{1}{|c|}{ Exogenous variables } & \multicolumn{1}{|c|}{ Name (type) } & Value \\
\hline Self-reported knowledge on organic foods & & \\
High (3) & KNOW & 44.4 \\
Medium (2) & & 48.42 \\
& & 7.11 \\
\hline Objective knowledge on organic foods & & \\
\hline They are free GMOs (dummy) & GMOs & $78 \%$ \\
\hline They are natural (dummy) & NATURAL & $63 \%$ \\
\hline They support the animal welfare (dummy) & ANIMAL & $72 \%$ \\
& WELFARE & \\
\hline They content 95\% of organic ingredients at least (dummy) & 95_INGREDIENTS & $77 \%$ \\
\hline
\end{tabular}

Table 3. Self-reported knowledge and organic knowledge

The second set of questions were related to organic food consumption (consumption level, intention to purchase, frequency of purchase, perceived quality, place of purchase, etc.). Finally, several questions about consumers' attitudes towards organic food products and environmental aspects were included.

Table 4 presents the definition of the endogenous variables. More than $50 \%$ of consumers declare to be an habitual buyer of organic food products; and $82 \%$ of them are willingness 
to buy them (82\%). Moreover, around 59\% of Italian consumers state that probably yes or definitely yes they pay attention to organic label when shopping organic food products.

\begin{tabular}{|c|c|c|c|}
\hline $\begin{array}{c}\text { Variable definition } \\
\text { Endogenous variables }\end{array}$ & Sources & Name (type) & Value \\
\hline $\begin{array}{l}\text { Purchase organic food products } \\
\text { Habitual }=3 \\
\text { Occasion }=2 \\
\text { Never=1 }\end{array}$ & Chen (2008) & $\mathrm{OP}$ & $\begin{array}{l}50.7 \\
28.7 \\
20.5\end{array}$ \\
\hline $\begin{array}{l}\text { Intention to purchase organic food } \\
\text { products } \\
\text { Yes }=1 \\
\text { No=0 }\end{array}$ & Chen (2008) & IP & $\begin{array}{l}81.9 \\
18.0\end{array}$ \\
\hline $\begin{array}{l}\text { Do you pay attention on organic label } \\
\text { when shopping? } \\
\text { Definitely no (1) } \\
\text { Probably No (2) } \\
\text { Indifferent (3) } \\
\text { Probably Yes (4) } \\
\text { Definitely yes (5) }\end{array}$ & Chen (2008) & ORG_LABEL & $\begin{array}{c}6.3 \\
9.5 \\
25.5 \\
36.8 \\
21.6\end{array}$ \\
\hline
\end{tabular}

Table 4. Endogenous variables definition

The definition of the psychological variables used in the model has been done based on previous empirical papers (Table 5). Respondents were asked to indicate their agreement or disagreement with the statements provided using a five point Likert scale where one indicates strong disagreement and five, strong agreement. The scale items for the different aspects and the empirical papers used are shown in table 5, while lifestyles are showed in table 6.

\begin{tabular}{|c|c|c|c|}
\hline Exogenous variables & Source & Name(type) & Value \\
\hline Attitudes towards organic food products & & & \\
\hline Organic food products are healthier & \multirow{8}{*}{$\begin{array}{l}\text { Michaelidou and } \\
\text { Hassan (2010) } \\
\text { Gil et al. (2000) } \\
\text { Chen (2007) }\end{array}$} & HEALTH & 3.7 \\
\hline $\begin{array}{l}\text { Organic food products have superior } \\
\text { quality }\end{array}$ & & QUALITY & 4.1 \\
\hline Organic food products are safer & & SAFETY & 3.9 \\
\hline $\begin{array}{l}\text { Organic food products seem to be } \\
\text { fresher than conventional ones }\end{array}$ & & FRESH & 3.5 \\
\hline $\begin{array}{l}\text { Organic food products are the same as } \\
\text { conventional ones }\end{array}$ & & SAME & 2.9 \\
\hline $\begin{array}{l}\text { Organic food products are more } \\
\text { expensive }\end{array}$ & & EXPENSIVE & 3.9 \\
\hline $\begin{array}{l}\text { Organic food products are } \\
\text { environmental friendly }\end{array}$ & & ENVIRON & 3.8 \\
\hline Organic food products are in fashion & & FASHION & 3.0 \\
\hline
\end{tabular}




\begin{tabular}{|c|c|c|c|}
\hline Exogenous variables & Source & Name(type) & Value \\
\hline \multicolumn{4}{|l|}{ Attitudes towards organic food purchase } \\
\hline $\begin{array}{l}\text { I believe that buying organic food } \\
\text { products is good }\end{array}$ & \multirow[t]{2}{*}{$\begin{array}{l}\text { Chen (2007) } \\
\text { Chen (2008) }\end{array}$} & GOOD & 3.9 \\
\hline I really support organic purchase & & SUPPORT & 4.1 \\
\hline \multicolumn{4}{|l|}{ Subjective norm } \\
\hline $\begin{array}{l}\text { Most people who are important for me } \\
\text { think that I should buy organic food } \\
\text { products }\end{array}$ & $\begin{array}{l}\text { Bredahl (2001) } \\
\text { Chen (2007) } \\
\text { Chen (2008) } \\
\end{array}$ & SNORM & 3.6 \\
\hline \multicolumn{4}{|l|}{ Perceived behavioral control } \\
\hline $\begin{array}{l}\text { Whether I will eventually buy organic } \\
\text { food products is entirely up to me }\end{array}$ & \multirow{2}{*}{$\begin{array}{l}\text { Bredahl (2001) } \\
\text { Chen (2007) } \\
\text { Chen } \\
(2008)\end{array}$} & CONTROL & 3.5 \\
\hline $\begin{array}{l}\text { If organic food products were available } \\
\text { in the shops, I do not think I would ever } \\
\text { be able to do so }\end{array}$ & & DIFFICULTY & 2.8 \\
\hline Ethical dimension & \multirow{4}{*}{$\begin{array}{l}\text { Arvola et al. (2009) } \\
\text { Thøgersen (2002) }\end{array}$} & & \\
\hline $\begin{array}{l}\text { I feel I ought to choose organic food } \\
\text { products }\end{array}$ & & MORAL & 3.1 \\
\hline $\begin{array}{l}\text { I fell obligation to choose organic food } \\
\text { products }\end{array}$ & & PROMOTION & 2.3 \\
\hline $\begin{array}{l}\text { I feel I should choose organic food } \\
\text { products }\end{array}$ & & FEELSHOULD & 2.7 \\
\hline
\end{tabular}

Table 5. Psychological variable definition

\begin{tabular}{|l|l|l|c|}
\hline \multicolumn{1}{|c|}{$\begin{array}{c}\text { Exogenous variables } \\
\text { Lifestyles }\end{array}$} & Name(type) & Value \\
\hline Consumer do exercise & & EXCISE & 51.6 \\
\hline $\begin{array}{l}\text { Consumer avoid snaking during } \\
\text { between lunch and dinner }\end{array}$ & NOSNACK & 3.17 \\
\hline Consumer avoid to be stressed & & STRESS & 3.43 \\
\hline
\end{tabular}

Table 6. Lifestyles

\section{Results}

The estimated parameters for the model defined by [1], [3] and [5] equations, using variables in table 2,3,4,5, and 6 are presented in table 7. Only exogenous variables statistically different from zero, at a significant level of 0.05 , have been finally included. Results show that correlations between equations are significant at $5 \%$ level. It means that errors for all equations are correlated. Therefore, we can conclude that the equations are not independent and that the simultaneous estimation of both equations in the model is the appropriate approach to obtain consistent parameter estimates. 
The organic label equation (ORG_LABEL) includes socio-demographic characteristics, selfreported knowledge, objective knowledge, and lifestyles (FEMALE, LW_INC, KNOW, GMOs, NOSNACK and STRESS). FEMALE has a positive significant effect on paying attention to organic label, while LW_INC is negative. Findings are in accordance with Canavari et al. (2002); Millock et al. (2003); Lockie et al. (2004), Tsakiridou et al.( 2006); Gracia and de Magistris (2008). Moreover, the positive and statistically significant estimated coefficient for the variable KNOW indicates that, if consumers show a high degree of selfreported organic knowledge, they are more likely to pay attention on organic label when shopping. However, only the variable GMOs related with organic knowledge has been found with a positive sign and it is statistically significant.

On the other hand, as we expected from other studies (Schifferstein and Oude Ophuis, 1998; Chryssohoidis and Krystallis, 2005; de Magistris and Gracia, 2009) variables related to lifestyles (NOSNACK and STRESS) are statistically significant, meaning that those consumers who usually do not have snack and they try not to stress are more likely to pay attention on organic label when shopping.

To pay attention to organic food label (ORG_LABEL) has been statistically significant on the intention to purchase (IP) equation. The positive coefficient associated with the ORG_LABEL variable in the intention to purchase equation indicates that the consumers who pay attention to the organic labels are more likely to buy organic food products. As we expected there is a significant relation between the intention to purchase organic food products (IP) and other variables related with attitudes towards purchase (GOOD). In addition, the positive and statistically significant estimate coefficients for the HEALTH and FRESH variables indicate that the more consumers believe that organic foods are healthier and fresher than conventional food ones, the more likely they are to buy organic food products. Finally, there is a positive and significant relation between the intention to purchase organic food products and the perceived behavior control (DIFFICULTY). These findings are consistent with those reported in Magnusson et al. (2001), Fotopoulos and Krystallis ( 2002), Zanoli and Naspetti (2002), Padel and Foster (2005) Chryssohoidis and Krystallis (2005), Tarkianen and Sundqvist (2005), Honkanen et al. (2006) and, Thogersen (2007). However, subjective norms (SNORM) and moral norms (MORAL) have not found statistically significant from zero. Finally, the intention to purchase organic food (IP) estimated parameter is positive and statistically significant in final organic purchase decision (OP). This means that as Ajzen postulates, the intention to purchase is the best predictor of final behavior, in our case organic food purchase. Only one additional variable, moral norm (MORAL) positively influences the final purchase decision.

We calculated the marginal effects to assess the effects of the exogenous variables on ORG_LABEL, IP, and OP variables (ordinal variables). In this specific case, and for the continuous exogenous variables, effects are calculated by means of the partial derivatives of the probabilities with respect to a given exogenous variable. In the case of dummy variables, the marginal effects are calculated taking the difference between the predicted probabilities in the respective variables of interest, changing from 0 to 1 and holding the rest constant. The change in predicted probabilities gives a more accurate description of the marginal effect of a dummy variable on event probability, than predicting the probability at the mean level of the dummy variable. The marginal effects for the continuous variables and for the dummy variables are shown in Tables 8, 9 and 10. 


\begin{tabular}{|c|c|c|c|c|c|c|c|c|c|}
\hline \multirow{3}{*}{$\begin{array}{l}\text { Coefficients } \\
\text { Intercept }\end{array}$} & \multicolumn{3}{|c|}{ ORG_LABEL } & \multicolumn{3}{|c|}{ IP } & \multicolumn{3}{|c|}{ OP } \\
\hline & \multirow{2}{*}{$\begin{array}{c}\text { Estimates } \\
-0.798\end{array}$} & \multicolumn{2}{|c|}{ t-ratio } & \multirow{2}{*}{$\begin{array}{c}\text { Estimates } \\
0.44\end{array}$} & \multicolumn{2}{|c|}{ t-ratio } & \multirow{2}{*}{$\begin{array}{c}\text { Estimates } \\
1.57\end{array}$} & \multicolumn{2}{|c|}{ t-ratio } \\
\hline & & -2.21 & * & & 2.88 & * & & 6.76 & ** \\
\hline FEMALE & 0.29 & 2.24 & * & & & & & & \\
\hline LW_INC & -0.543 & -3.26 & * & & & & & & \\
\hline KNOW & 0.202 & 1.91 & * & & & & & & \\
\hline GMOs & 0.55 & 3.32 & * & & & & & & \\
\hline NOSNACK & 0.267 & 4.33 & * & & & & & & \\
\hline STRESS & 0.224 & 3.60 & * & & & & & & \\
\hline ORG_LABEL & & & & 0.44 & 4.04 & ** & & & \\
\hline GOOD & & & & 0.37 & 4.05 & ** & & & \\
\hline HEALTH & & & & 0.29 & 2.90 & ** & & & \\
\hline FRESH & & & & 0.20 & 1.71 & ** & & & \\
\hline DIFFICULTY & & & & -0.25 & -2.22 & ** & & & \\
\hline IP & & & & & & & 0.31 & 3.82 & ** \\
\hline MORAL & & & & & & & 0.312 & 3.68 & ** \\
\hline $\mathrm{N}$ & 380 & & & & & & & & ** \\
\hline $\begin{array}{l}\text { Log } \\
\text { Likelihood }\end{array}$ & -704.2 & & & & & & & & ** \\
\hline$\mu_{2}$ & 0.60 & 5.55 & * & & & & 0.90 & 9.92 & ** \\
\hline$\mu_{3}$ & 1.49 & 11.19 & * & & & & & & \\
\hline$\mu 4$ & 2.66 & 17.14 & & & & & & & \\
\hline Correlations & & & & & & & & & \\
\hline $\begin{array}{l}\text { Organic label } \\
\text { paying } \\
\text { attention }\end{array}$ & & & & 0.32 & 1.91 & * & 0.16 & 2.05 & ** \\
\hline $\begin{array}{l}\text { Intention to } \\
\text { purchase }\end{array}$ & & & & & & & 0.75 & 7.59 & ** \\
\hline
\end{tabular}

$\left(^{* *}\right)\left(^{*}\right)$ denotes statistical significance at the $1(5)(10)$ per cent significance levels

Table 7. Results of Multivariate probit model

With respect to the marginal effects on consumers' pay attention to organic label when shopping (table 8), results indicate that female consumers have a higher probability to pay attention to organic label. Moreover, as we expected, there is a negative relationship between low income and paying attention to organic label. One of possible explication of these results is that people with low income are more likely to have a lower attention to organic labeling when shopping because of the higher price of the products.

The marginal effects of self-reported and objective knowledge are as expected. Those consumers who believe that organic food label is GMOs free, and they state a higher selfreported knowledge of these products are more likely to state a higher probability to pay 
attention to organic label when shopping. Finally, those consumers who strongly agree with not snaking and avoiding stress life are more likely to pay attention to organic food labels. Regarding the intention to purchase organic food products, the results indicate that consumers with higher probability to pay attention to organic labels (ORG_LABEL) are more likely to be willing to buy organic food products (table 9). As consumers present more positive attitudes towards the purchase (GOOD) they are more likely to buy them. Moreover, the more subjects consider difficult to find organic food products where they usually shop, the less likely to be willing to buy them. As we expected, those consumers believe that organic food products are fresher and healthier (FRESH, HEALTH) than conventional ones, they are more likely to purchase them. Finally, with respect to the final purchase of organic food (table 10), findings suggest, as expected, that consumer who strongly agree that it is moral to buy organic food products (MORAL) they are more likely to purchase them. Finally, as we expected the marginal effects of the intention to purchase organic food products are positive. Those consumers who strongly state the intention to purchase organic food products are more likely to finally purchase them.

\begin{tabular}{|l|l|l|l|l|l|}
\hline & $\begin{array}{l}\text { Prob } \\
\text { ORG_LABEL } \\
=1\end{array}$ & $\begin{array}{l}\text { Prob } \\
\text { ORG_LABEL } \\
=2\end{array}$ & $\begin{array}{l}\text { Prob } \\
\text { ORG_LABEL } \\
=3\end{array}$ & $\begin{array}{l}\text { Prob } \\
\text { ORG_LABEL } \\
=4\end{array}$ & $\begin{array}{l}\text { Prob } \\
\text { ORG_LABEL } \\
=5\end{array}$ \\
\hline Variable & & & & & \\
\hline FEMALE & $-0.028^{* *}$ & $-0.038^{* *}$ & $-0.052^{* *}$ & $0.0407^{* *}$ & $0.077^{* * *}$ \\
\hline LW_INC & $0.057^{* *}$ & $0.066^{* *}$ & $0.074^{* *}$ & $-0.083^{* *}$ & $-0.112^{* * *}$ \\
\hline KNOW & $-0.017^{* *}$ & $-0.025^{* *}$ & $-0.037^{* *}$ & $0.030^{* * *}$ & $0.055^{* * *}$ \\
\hline GMOs & $-0.051^{* *}$ & $-0.052^{* *}$ & $-0.064^{* *}$ & $0.065^{* *}$ & $0.091^{* * *}$ \\
\hline NOSNACK & $-0.023^{* *}$ & $-0.033^{* *}$ & $-0.049^{* *}$ & $0.033^{* *}$ & $0.073^{* * *}$ \\
\hline STRESS & $-0.019^{* *}$ & $-0.027^{* *}$ & $-0.040^{* *}$ & $0.027^{* *}$ & $0.059^{* *}$ \\
\hline
\end{tabular}

Table 8. Marginal effects of paying attention to organic labeling

\begin{tabular}{|l|c|}
\hline & $\begin{array}{l}\text { Prob } \\
\text { Intention to purchase }=1\end{array}$ \\
\hline Variable & $0.062^{* * *}$ \\
\hline ORG_LABEL & $0.078^{* * *}$ \\
\hline GOOD & $0.052^{* *}$ \\
\hline HEALTH & $0.039^{* * *}$ \\
\hline FRESH & $-0.047^{* *}$ \\
\hline DIFFICULTY & 0.07 . \\
\hline
\end{tabular}

Table 9. Marginal effects of the intention to purchase organic food products

\begin{tabular}{|l|l|l|l|}
\hline & $\begin{array}{l}\text { Prob } \\
\text { OP=1 }\end{array}$ & $\begin{array}{l}\text { Prob } \\
\text { OP=2 }\end{array}$ & $\begin{array}{l}\text { Prob } \\
\text { OP=3 }\end{array}$ \\
\hline Variable & & & \\
\hline IP & $-0.349^{* * *}$ & $0.167^{* *}$ & $0.182^{* * *}$ \\
\hline MORAL & $-0.105^{* * *}$ & $0.037^{* *}$ & $0.678^{* * *}$ \\
\hline
\end{tabular}

Table 10. Marginal effects of organic food purchase 


\section{Final remarks}

In 2010 a new organic labelling was introduced in the European Union in order to increase the trust among European consumers towards organic food products and communicate them more environmental signals. The new label is compulsory and used only in those products which contain at least $95 \%$ of the organic agricultural ingredients. The main aim of new logo is to allow citizens to be more informed and then increase organic consumers' purchase with related positive economic effects on marginalized and rural areas. Hence, this paper has investigated the effects of paying attention to organic labelling on the intention to buy organic food products in Italy and how the intention drives to the final purchase. Moreover, it has also provided additional evidence regarding those psychological factors affecting the intention to purchase organic food products.

The results indicate that those consumers who pay attention to organic labeling when shopping are more likely to be willingness to buy organic food products. In addition, women and people with high incomes are those who are more likely to use organic labeling. And thus, they are to be willing to buy organic food products. On the other hand, the degree of paying attention to organic label is strongly and positively linked to the degree of knowledge. The results show that increasing organic knowledge is of paramount importance to increase the attention paid by consumers to organic label. As the Theory of Planned Behavior states, findings also show that other factors explain the intention to purchase organic food products such as attitudes towards their purchase. Consumers with positive attitudes towards the purchase are more likely to be willing to buy organic food. In particular, consumers who support buying organic foods are more likely to be willing to purchase them. However, in contrast with previous studies, the intention to purchase of Italian consumers is not affected by subjective norms or environmental attitudes when shopping. Finally, ethical dimension is considered one of main factors driving organic food purchases because Italian consumers who feel the ethical obligation to choose organic food products are the ones that finally purchase them. These results provide valuable information on consumers' purchase behavior of organic food products to help policy makers at European, National and Regional level. In particular, the results are very useful for policy makers when designing their respective organic farming policies for Italy. First, policy makers should take into account that household income still represents a barrier which limits the expansion of organic food products in the Italian market. Therefore, they should strongly support organic farmers by substantial subventions in order to decrease their costs of certifications and lead them to be more competitive in food market. Second, our study confirms the results of previous studies which showed that organic knowledge represents a key issue that organic farmers have to take into account in order to sell their products. To illustrate, organic food products should be supported by investments in promotion actions which will result in easy identifiable by consumers trough new organic labeling providing consumers more information of other organic food characteristics, such as the percentage of organic ingredients, animal welfare and GMOs free. Finally, since ethical aspects in organic food purchase influences consumers' purchase decisions of organic food, future informational campaigns and promotion actions will also focus on making consumers more aware of the ethical dimension of organic food products. In particular, they also communicate the economic and environmental benefits on context where organic farmers operate in terms of the improvement of farmers' incomes and retaining population. 


\section{Acknowledgements}

This paper has been written within of the project, funded by the European Union, “FOODLABELS_PIOF-GA-2009-253323

\section{References}

Aertsen, J., Verbeke, W., Mondelaers, K. \& Van Huylenbroeck, G. (2009). Personal determinants of organic food consumption: a review. British Food Journal, 1140-1167, 111:10.

Ajzen, I. (1991). The theory of planned behaviour. Organizational Behaviour and Human Decision Processes, Vol. 50, pp. 179-211.

Arvola, A., Vassallo, M., Dean, M., Lampila, P., Saba, A., Lahteenmaki, L. \& Shepherd, R. (2008). Predicting intentions to purchase organic food: The role of affective and moral attitudes in the Theory of Planned Behaviour. Appetite, Vol. 50 No. 2-3, pp. 443-454.

Bredahl, L. (2001). Determinants of consumer attitudes and purchase intentions with regard to genetically modified foods - Results of a cross-national survey. Journal of Consumer Policy, 24, 23-61.

Brunsø, K. Scholderer, J. \& Grunert, K. G. (2004). Testing relationships between values and food-related lifestyle: results from two European countries. Appetite, 43, 195-205.

Canavari, M., Bazzani, G.M., Spadoni, R. and Regazzi, D. (2002). Food safety and organic fruit demand in Italy: a survey. British Food Journal, Vol. 104 Nos 3/4/5, pp. 220-32.

Chen, M.F. (2007). Consumer attitudes and purchase intentions in relation to organic foods in Taiwan: moderating effects of food-related personality traits. Food Quality and Preference, Vol. 18, pp. 1008-21.

Chen, M. F. (2008). An integrated research framework to understand consumer attitudes and purchase intentions toward genetically modified foods. British Food Journal, 110 (6), 559-579.

Chryssohoidis, G. M. \& Krystallis, A. (2005). Organic consumers' personal values research: Testing and validating the list of values (LOV) scale and implementing a valuebased segmentation task. Food Quality and Preference, Vol. 16 No. 7, pp. 585-599.

Dean, M., Raats, M. M. and Shepherd, R. (2008). Moral concerns and consumer choice of fresh and processed organic foods. Journal of Applied Social Psychology, Vol. 38 No. 8, pp.2088-2107.

de Magistris T. \& Gracia A. (2009). The decision to buy organic food products in Southern Italy. British Food Journal, Vol. 110 Iss: 9, pp.929 - 947.

European Commission (1992) Regulation (EEC) No 2092/21, on organic production of agricultural products and indications referring thereto on agricultural products and foodstuffs

European Commission (2000) Commission Regulation (EC) No 331/2000 .Amending Annex V to Council Regulation (EEC) No 2092/91 on organic production of agricultural products and indications referring thereto on agricultural products and foodstuffs

European Council(2007) Regulation (EC) No. 834/2007 of 28 June 2007 on organic production and labelling of organic products and repealing Regulation (EEC) No 2092/91 
European Commission (2010).Commission Regulation (EU) No 271/2010 on 24 march amending Regulation (EC) No 889/2008 laying down detailed rules for the implementation of Council Regulation (EC) No 834/2007, as regards the organic production logo of the European Union

Fotopoulos, C. \& Krystallis, A. (2002). Purchasing Motives and Profile of the Greek Organic Consumer: A Countrywide Survey. British Food Journal, 104(3/5):232-260

Gil, J. M., Gracia, A., \& Sanchez, M. (2000). Market segmentation and willingness to pay for organic products in Spain. International Food and Agribusiness Management Review, 3, 207-226.

Gracia, A. \& de Magistris, T. (2008). The demand for organic foods in the South of Italy: A discrete choice model. Food Policy, vol. 33(5), pages 386-396, October

Grunert, K.G. \& Brunsø, K. (1997). Food-related lifestyle: development of cross-culturally valid instrument for market surveillance", in Kahle, L.R. and Chiagouris, L. (Eds), Value, Lifestyle and Psychographics, Lawrence Erlbaum Associates, Hillsdale, NJ, pp. 337-54.

Guido, G., Prete, M., Peluso, A., Maloumby-Baka, R. \& Buffa, C. (2010). The role of ethics and product personality in the intention to purcahse organic food products: a structural equation modeling approach. International Review of Economics, 57, 79-102.

Hajivassiliou, V. A., \& McFadden, D. (1998). The method of simulated scores for the estimation of LDV models. Econometrica, 66, 863-896.

Hill, H. \& Lynchehaun, F. (2002). Organic milk: Attitudes and consumption patterns. British Food Journal, 104 (7), pp. 526-542.

Honkanen, P., Verplanken, B., \& Olsen S. O. (2006). Ethical values and motives driving organic food choice. Journal of Consumer Behaviour, 5 (5), 420-431.

ISTAT, 2008. I consumi delle famiglie. Webpage: https://www.istat.it

Lockie, G., Lyons, K., Lawrence, G. \& Mummery, K. (2002). Eating 'green': Motivations behind organic food consumption in Australia. European Society for Rural Sociology, 42(1):23-40.

Magnusson, M. K., Arvola, A., Koivisto Hursti, U., Aberg, L. \& Sjöden, P. O. (2003). Choice of organic foods is related to perceived consequences for human health and to environmentally friendly behaviour. Appetite, Vol. 40 No. 2, pp. 109-117.

Michaelidou, N., \& Hassan, L.M. (2008). The role of health consciousness, food safety concern and ethical identity on attitudes and intentions towards organic food. International Journal of Consumer Studies, 32, 163-170.

Millock, K., Wier, M. \& Andersen, L.M. (2004). Consumer's demand for organic foodsattitudes, value and purchasing behaviour, selected paper for presentation at the XIII Annual Conference of European Association of Environmental and Resource Economics, Budapest, 25-28 June.

Padel, S. \& Foster, C. (2005). Exploring the gap between attitudes and behaviour. British Food Journal, Vol. 107 No. 8, pp. 606-25.

Poelman, A., Mojet, J., Lyon, D. \& Sefa-Dedeh, S. (2008). The influence of information about organic production and fair trade on preference for and perception of pineapple. Food Quality and Preference, Vol. 19 No. 1, pp. 114-21.

Saba, A. \& Messina, F. (2003). Attitudes towards organic food and risk/benefit perception associated with pesticides. Food Quality and Preference, Vol. 14, pp. 637-45. 
Shaw, D. \& Clarke, I. (1999). Belief formation in ethical consumer groups: an exploratory study. Marketing Intelligence and Planning, Vol. 17 No. 2 and 3, pp. 109-19.

Schifferstein, H.N.J. \& Oude, P.A.M.(1998). Health-related determinants of organic food consumption in The Netherlands. Food Quality and Preference, Vol. 9 No. 3, pp. 11933.

Smith, S. \& Paladino, A. (2010). Eating clean \& green? Investigating consumer motivations towards the purchase of organic food. Australasian Journal of Marketing, 18(2): pp 93104.

Sparks, P. \& Shepherd, R. (1992) Self-Identity and the Theory of Planned Behavior: Assesing the Role of Identification with "Green Consumerism. Social Psychology Quarterly. 388-399

Tarkiainen, A. \& Sundqvist, S. (2005). Subjective norms, attitudes and intentions of Finnish consumers in buying organic food. British Food Journal, Vol. 107 No. 10-11, pp. 808822 .

Thøgersen, J. (2007a). Consumer decision-making with regard to organic food products. in Vaz, M. T. d. N., Vaz, P., Nijkamp, P. \& Rastoin, J. L. (Eds.) Traditional Food Production Facing Sustainability: A European Challenge; Ashgate.

Thøgersen, J. (2007b) The motivational roots of norms for environmentally responsible behaviour. Nordic Consumer Policy Research Conference. Helsinki.

Thøgersen, J. \& Olander, F. (2006). The dynamic interaction of personal norms and environment-friendly buying behavior: A panel study. Journal of Applied Social Psychology, Vol. 36 No. 7, pp. 1758-1780.

Thøgersen, J. (2002). Direct experience and the strength of the personal norm - Behavior relationship, Psychology \& Marketing, Vol. 19 No. 10, pp. 881-893.

Tsakiridou, E., Mattas, K. \& Tzimitra-Kaloglanni, I. (2006), The influence of consumer characteristics and attitudes on the demand for organic olive oil, Journal of International Food E Agribusiness Marketing, Vol. 18 No. 3-4, pp. 23-31.

Yiridoe, E.K., Bonti-Ankomah, S. \& Martin, R.C. (2005). Comparison of consumer's perception towards organic versus conventionally produced foods: a review and update of the literature. Renewable Agriculture and Food System, Vol. 20 No. 4, pp. 193-205.

Verhoef, P. C. (2005), Explaining purchases of organic meat by Dutch consumers, European Review of Agricultural Economics, Vol. 32, pp. 245-267.

Von Alvesleben, R. (1997), “Consumer behaviour", in Padberg, D.I., Ritson, C. and Albisu, L.M. (Eds), Agro-food Marketing, CAB International, New York, NY.

Zanoli, R. \& Naspetti, S. (2002). Consumer motivations in the purchase of organic food: a means-end approach. British Food Journal, Vol. 104 No. 8, pp. 643-53. 


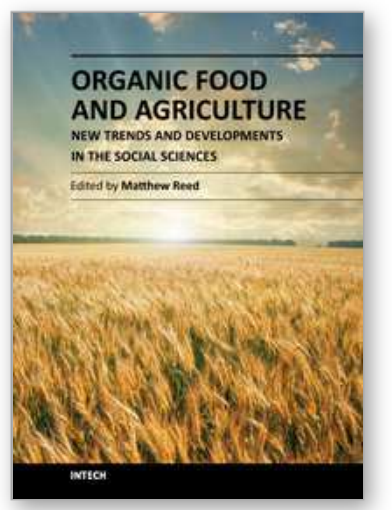

\author{
Organic Food and Agriculture - New Trends and Developments in \\ the Social Sciences \\ Edited by Dr Matthew Reed
}

ISBN 978-953-307-764-2

Hard cover, 216 pages

Publisher InTech

Published online 05, January, 2012

Published in print edition January, 2012

The global phenomenon of organic food and farming, after three decades of progress, faces new challenges as markets mature and the impacts of the global recession start to change consumers and farmers' expectations. This global survey of the organic food and farming considers how the social sciences have come to understand in what way consumers make their choices as they shop, and how new national markets evolve. It also surveys how established organic sectors in North America and Europe are changing in response to the changes, that in part, the organic movement has created. Moving from a wide range of social science disciplines, methodologies and perspectives, this book represents an excellent starting place for new readers, and offers innovation to those already familiar with the literature.

\title{
How to reference
}

In order to correctly reference this scholarly work, feel free to copy and paste the following:

Tiziana de Magistris and Azucena Gracia (2012). Do Consumers Pay Attention to the Organic Label When Shopping Organic Food in Italy?, Organic Food and Agriculture - New Trends and Developments in the Social Sciences, Dr Matthew Reed (Ed.), ISBN: 978-953-307-764-2, InTech, Available from:

http://www.intechopen.com/books/organic-food-and-agriculture-new-trends-and-developments-in-the-socialsciences/do-consumers-pay-attention-to-the-organic-label-when-shopping-organic-food-in-italy-

\section{INTECH}

open science | open minds

\author{
InTech Europe \\ University Campus STeP Ri \\ Slavka Krautzeka 83/A \\ 51000 Rijeka, Croatia \\ Phone: +385 (51) 770447 \\ Fax: +385 (51) 686166 \\ www.intechopen.com
}

\author{
InTech China \\ Unit 405, Office Block, Hotel Equatorial Shanghai \\ No.65, Yan An Road (West), Shanghai, 200040, China \\ 中国上海市延安西路65号上海国际贵都大饭店办公楼405单元 \\ Phone: +86-21-62489820 \\ Fax: +86-21-62489821
}


(C) 2012 The Author(s). Licensee IntechOpen. This is an open access article distributed under the terms of the Creative Commons Attribution 3.0 License, which permits unrestricted use, distribution, and reproduction in any medium, provided the original work is properly cited. 